\title{
KOMPUTERISASI PERHITUNGAN PARAMETER MARSHALL UNTUK RANCANGAN CAMPURAN BETON ASPAL
}

\author{
Deni Setiawan \\ Dosen Luar Biasa, Jurusan Teknik Sipil, Universitas Kristen Maranatha \\ Mahasiswa S2, Program Magister Teknik Sipil, Universitas Parahyangan \\ e-mail: den9851@yahoo.com
}

\begin{abstract}
Until now, calculation of Mashall test is done with manually by tables. There are some weakness if we do it with manually, like: much procedure must do, unaccuracy in calculation ( human errors), and not efficient in time. For that purpose hence required existence of program to overcoming or minimizes errors. The purpose of this paper is to computerize the calculation of Marshall test by utilizing Borland Delphi 7.0 programming. By statistical analysis, the comparition result of calculation manually and with program is $\mathrm{t}<\mathrm{t}_{\alpha}$, this means that program calculation is acceptable. Programming result of this Marshall test required some retouchings like performance to draw graph and performance to print graph.
\end{abstract}

Keywords: Marshall, programming, Borland Delphi 7.0.

\begin{abstract}
ABSTRAK
Selama ini perhitungan dan pengolahan hasil pengujian Marshall dilakukan secara manual dengan bantuan tabel. Perhitungan secara manual terdapat beberapa kelemahan di antaranya: banyaknya prosedur yang harus dilakuakan, adanya ketidaktelitian dalam perhitungan akibat kesalahan manusia (human error), dan tidak efisien dalam waktu. Untuk itu maka diperlukan adanya program yang mengatasi atau memperkecil kesalahan yang timbul. Tugas Akhir ini bertujuan untuk mengkomputerisasikan perhitungan pengujian Marshall dengan mempergunakan bahasa program Borland Delphi 7.0. Perbandingan perhitungan secara manual dan perhitungan secara program secara uji statistik diperoleh hasil $\mathrm{t}<\mathrm{t}_{\alpha}$ ini membuktikan bahwa perhitungan secara program dapat diterima. Pemrograman hasil pengujian Marshall ini diperlukan beberapa penyempurnaan yaitu kemampuan untuk menggambar grafik dan kemampuan untuk mencetak grafik.
\end{abstract}

Kata kunci: Marshall, programming, Borland Delphi 7.0.

\section{PENDAHULUAN}

Kinerja beton aspal dapat diperiksa dengan mempergunakan alat pemeriksaan Marshall. Untuk saat ini prosedur pengujian mengikuti SNI 06-2489-1991, atau AASHTO T 245-90, atau ASTM D1559-76. Perhitungan volume dan pengolahan hasil uji Marshall ini dilakukan secara manual dalam bentuk tabel dan grafik, dengan demikian ada beberapa kelemahan di antaranya:

1. Banyaknya prosedur perhitungan yang harus dilakukan.

2. Adanya ketidaktelitian dalam perhitungan akibat kesalahan manusia (human error).

3. Tidak efisien dalam waktu. 
Maka untuk mengatasi atau memperkecil kelemahan-kelemahan tersebut, perlu mengkomputerisasikan perhitungan selama proses pengujian Marshall, yaitu dengan menggunakan bahasa program Borland Delphi 7.0 yang berbasiskan visual di lingkungan Windows dan diproduksi oleh Microsoft. Penelitian ini dibatasi hanya untuk pemrograman perhitungan hasil pengujian dengan menggunakan alat Marshall untuk memperoleh kadar aspal optimum dan parameter Marshall lainnya dengan memasukkan data-data yang diperlukan.

\section{PENGUJIAN MARSHALL}

Kinerja beton aspal padat ditentukan melalui pengujian benda uji yang meliputi: Penentuan berat volume benda uji.

1. Pengujian nilai stabilitas, adalah kemampuan maksimum beton aspal padat menerima beban sampai terjadi kelelehan plastis.

2. Pengujian kelelehan (flow), adalah besarnya perubahan bentuk plastis dari beton aspal padat akibat adanya beban sampai batas keruntuhan.

3. Perhitungan Kuosien Marshall, adalah perbandingan antara stabilitas dan flow.

4. Perhitungan berbagai jenis volume pori dalam beton aspal padat (VIM, VMA, dan VFA).

5. Perhitungan tebal selimut atau film aspal.

Pengujian kinerja beton aspal padat dilakukan melalui pengujian Marshall, yang dikembangkan pertama kali oleh Bruce Marshall dan dilanjutkan oleh U.S. Corps. Engineer.

Alat Marshall merupakan alat tekan yang dilengkapi dengan proving ring (cincin penguji) berkapasitas $22,2 \mathrm{KN}$ (=5000 lbf) dan flowmeter. Proving ring digunakan untuk mengukur nilai stabilitas, dan flowmeter untuk mengukur kelelehan plastis atau flow. Benda uji Marshall berbentuk silinder berdiameter 4 inci $(=10,2 \mathrm{~cm})$ dan tinggi 2,5 inci $(=6,35 \mathrm{~cm})$. Prosedur pengujian Marshall mengikuti SNI 06-2489-1991, atau ASTM D 1559-76.

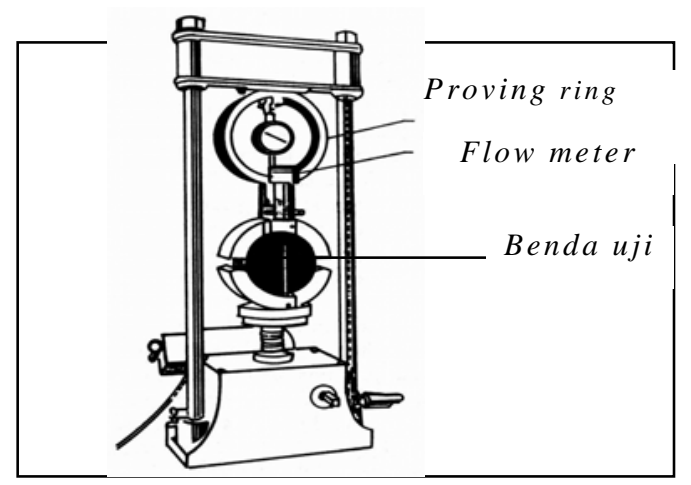

Gambar 2.4 Alat Marshall. 
Jadi, dari keenam butir pengujian yang umum dilakukan untuk menentukan kinerja beton aspal, terlihat bahwa hanya nilai stabilitas dan flow yang ditentukan dengan mempergunakan alat Marshall, sedangkan parameter lainnya ditentukan melalui penimbangan benda uji, dan perhitungan. Walaupun demikian, secara umum telah dikenali bahwa pengujian Marshall meliputi pengujian keenam butir di atas.

Secara garis besar pengujian Marshall meliputi:

1. Persiapan benda uji.

2. Penentuan berat jenis bulk dari benda uji.

3. Pemeriksaan nilai stabilitas dan flow.

4. Perhitungan sifat volumetrik benda uji.

\section{KOMPUTERISASI}

\subsection{Borland Delphi 7}

Bahasa pemrograman yang dipergunakan dalam Penelitian ini adalah mempergunakan Borland Delphi 7 untuk selanjutnya dalam Penelitian ini disebut Delphi. Delphi merupakan bahasa pemrograman yang mempunyai cakupan kemampuan yang luas dan sangat canggih. Berbagai jenis aplikasi dapat dibuat dengan Delphi, termasuk aplikasi untuk mengolah teks, grafik, angka, database dan aplikasi web.

Untuk mempermudah pemrograman dalam membuat program aplikasi, Delphi menyediaan fasilitas pemrograman yang sangat lengkap. Fasilitas pemrograman tersebut dibagi dalam dua kelompok, yaitu object dan bahasa pemrograman. Secara ringkas, object adalah suatu komponen yang mempunyai bentuk fisik dan biasanya dapat dilihat (visual). Object biasanya dipakai untuk melakukan tugas tertentu dan mempunyai batasan-batasan tertentu. Sedangkan bahasa pemrograman secara singkat dapat disebut sebagai kumpulan text yang mempunyai arti tertentu dan disusun dengan aturan tertentu serta untuk menjalankan tugas tertentu. Delphi menggunakan struktur bahasa pemrograman Object Pascal yang sudah dikenal di kalangan pemrogram. Gabungan dari object dan bahasa pemrograman ini sering disebut sebagai bahasa pemrograman berorientasi object atau Object Oriented Programming (OOP). 




Gambar 3.1 Tampilan dasar Delphi.

\subsection{Konsep Umum Program}

Sistem pemrograman perhitungan hasil pengujian Marshall ini, sistem pemrogramannya mempergunakan database. Hal ini disebabkan karena data yang diolah saling terkait satu dengan lainnya.

Untuk mempermudah pemrograman dan pengolahan data maka dipergunakan operasi dalam bentuk tabel seperti yang dilakukan dalam pengoperasian program Excel. Sedangkan untuk pengolahan fungsi regresi dipergunakan fasilitas bahasa Pascal yang telah disediakan oleh Delphi.

\subsubsection{Data Masukan}

Data masukkan untuk program ini dibagi menjadi dua yaitu:

1. Data masukkan untuk tabel perhitungan hasil pengujian Marshall.

Sebagai data masukkan untuk tabel perhitungan hasil pengujian Marshall antara lain:

a. Berat jenis bulk, $\mathrm{G}_{\mathrm{sb}}$.

b. Berat jenis aspal.

c. Kalibrasi proving ring.

d. Persentase berat aspal terhadap total agregat.

e. $\mathrm{G}_{\mathrm{mm}}$.

f. Berat benda uji di udara.

g. Berat benda uji dalam air.

h. Berat benda uji kering permukaan.

i. Isi benda uji. 
j. Bacaan dial.

k. Flow (kelelehan).

2. Data masukan untuk menampilkan grafik hasil perhitungan.

Sebagai data masukan untuk menampilkan grafik antara lain:

a. Koefisien fungsi regresi.

Koefisien fungsi regresi diperoleh dari hasil perhitungan program.

b. Syarat batas.

Syarat batas diperoleh dari ketentuan dari tabel sifat campuran beton aspal.

\subsubsection{Proses Data}

Proses data dalam program untuk tabel perhitungan hasil pengujian Marshall adalah sebagai berikut:

1. $\mathrm{B}=\frac{\mathrm{A}}{100+\mathrm{A}} \times 100$

2. $\mathrm{D}=\frac{\mathrm{G}_{\mathrm{sb}}+\mathrm{G}_{\mathrm{sa}}}{2}$

3. $\mathrm{H}=\mathrm{G}-\mathrm{F}$

4. $I=\frac{E}{H}$

5. $J=100 \times \frac{\left(D-G_{s b}\right)}{\left(G_{s e} \times G_{s b}\right)} \times$ Berat jenis aspal

6. $\mathrm{K}=\mathrm{A}-\left(\frac{\mathrm{K}}{100}\right) \times \mathrm{P}_{\mathrm{s}}$

7. $\mathrm{L}=100-\frac{\mathrm{J} \times \mathrm{P}_{\mathrm{s}}}{\mathrm{G}_{\mathrm{sb}}}$

8. $\mathrm{M}=100 \times \frac{\mathrm{C}-\mathrm{I}}{\mathrm{G}_{\mathrm{sb}}}$

9. $\mathrm{N}=\frac{100(\mathrm{~L}-\mathrm{M})}{\mathrm{M}}$

10. $\mathrm{R}=\mathrm{Q} \times$ kalibrasi proving ring.

11. $\mathrm{S}=\mathrm{R} \times$ faktor koreksi.

dengan:

$A=$ Persen berat aspal terhadap total agregat.

$\mathrm{B}=$ Persen berat aspal terhadap total campuran 
$\mathrm{C}=\mathrm{G}_{\mathrm{mm}}$.

$\mathrm{D}=\mathrm{G}_{\mathrm{se}}$

$\mathrm{E}=$ Berat benda uji di udara.

$\mathrm{F}=$ Berat benda uji dalam air.

$\mathrm{G}=$ Berat benda uji kering permukaan.

$\mathrm{H}=$ Volume bulk.

$\mathrm{I}=$ Berat jenis bulk, Gmb.

$\mathrm{J}=\mathrm{Pba}$.

$\mathrm{K}=$ Pbe.

$\mathrm{L}=\mathrm{VMA}$.

$\mathrm{M}=\mathrm{VIM}$.

$\mathrm{N}=$ VFA.

$\mathrm{O}=$ Bacaan dial.

$\mathrm{P}=$ Justifikasi $\mathrm{kg}$.

$\mathrm{Q}=$ Stabilitas Marshall.

$\mathrm{R}=$ Flow (kelelehan).

$\mathrm{S}=$ Marshall Quotient.

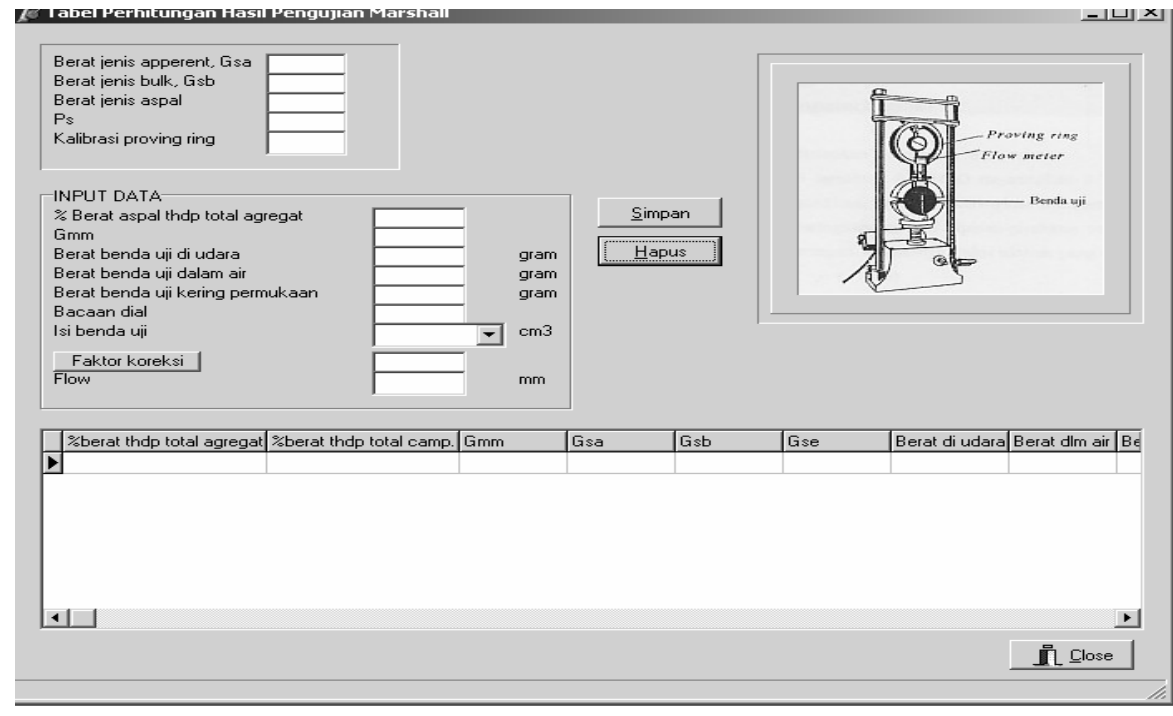

Gambar 3.2 Tampilan tabel perhitungan hasil pengujian Marshall.

\subsubsection{Data Keluaran}

Yang menjadi data keluaran dari program perhitungan hasil pengujian Marshall adalah ditampilkan dalam hasil eksekusi program sebagai berikut: 


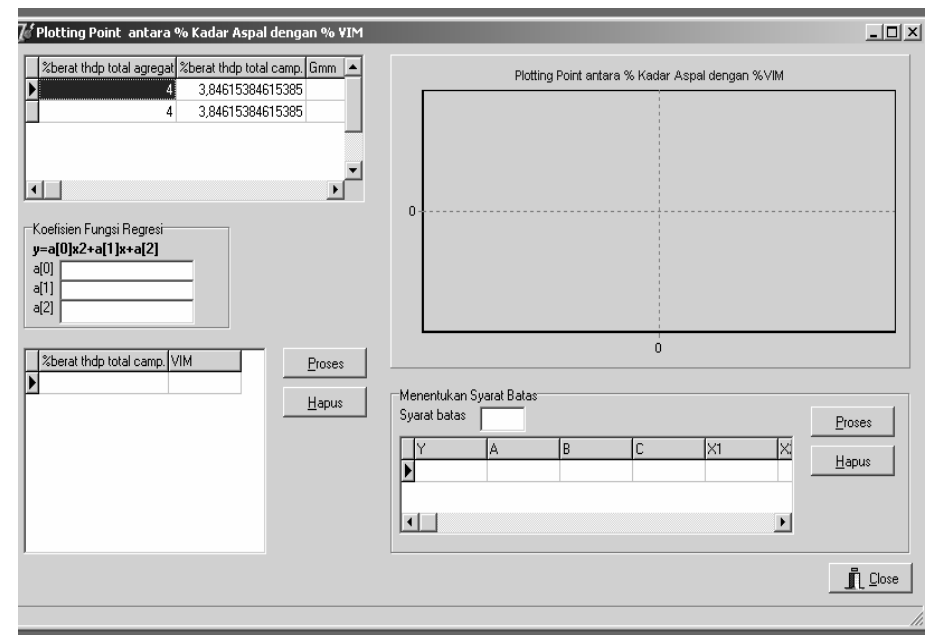

Gambar 3.3 Plotting point antara \% kadar aspal terhadap \% VIM.

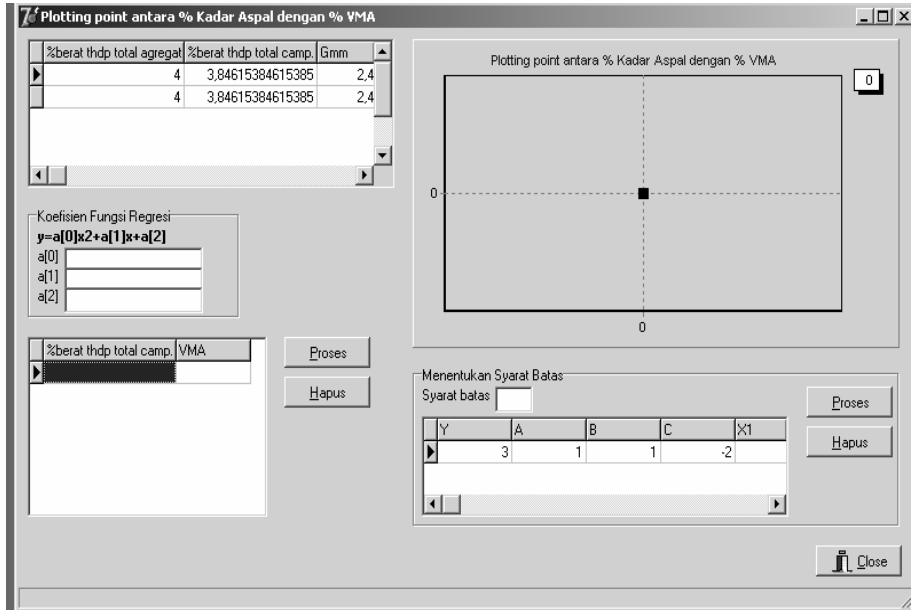

Gambar 3.4 Plotting point antara \% kadar aspal terhadap \% VMA.

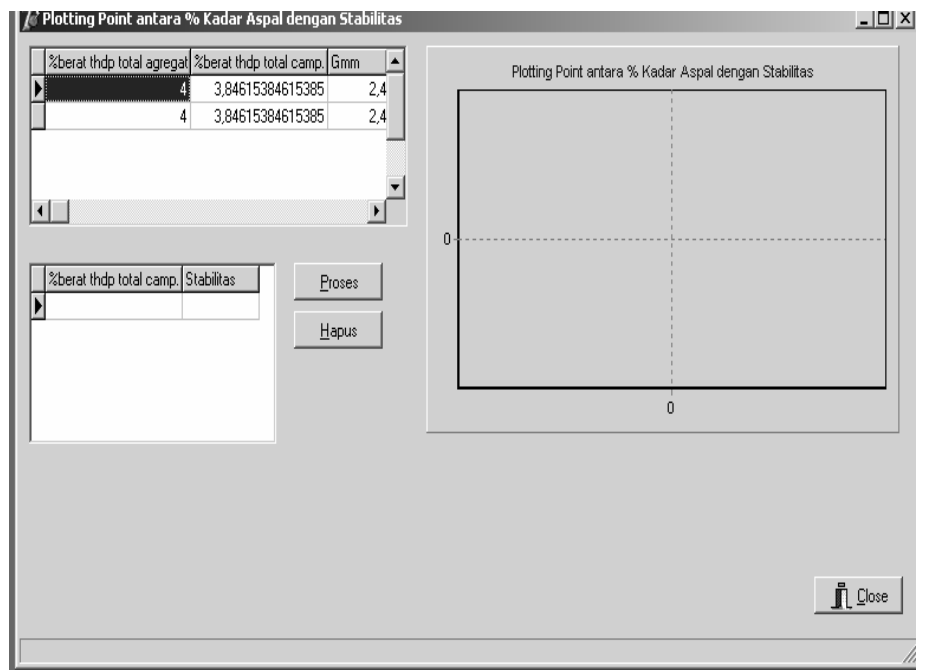

Gambar 3.5 Plotting point antara \% kadar aspal terhadap stabilitas. 


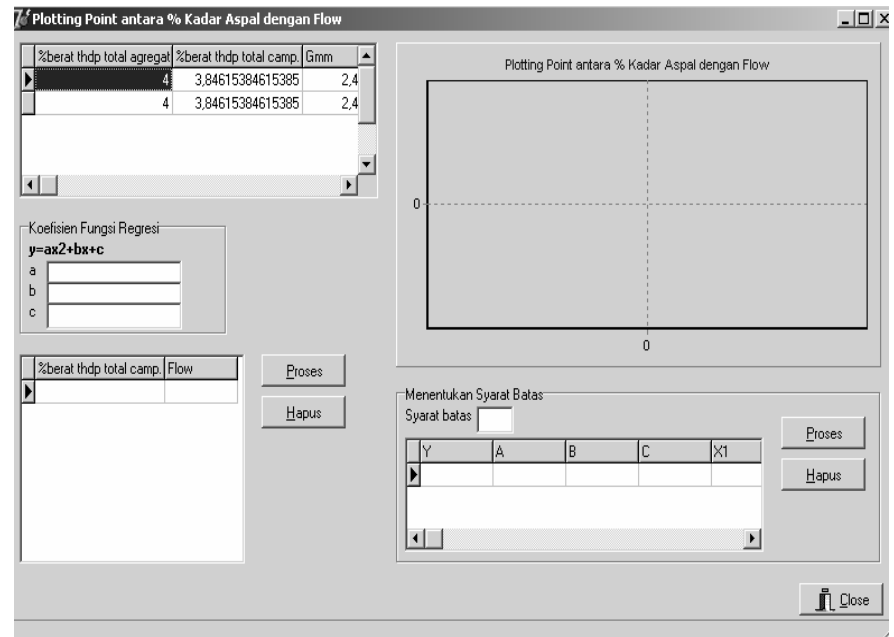

Gambar 3.6 Plotting point antara \% kadar aspal terhadap flow (Kelelehan).

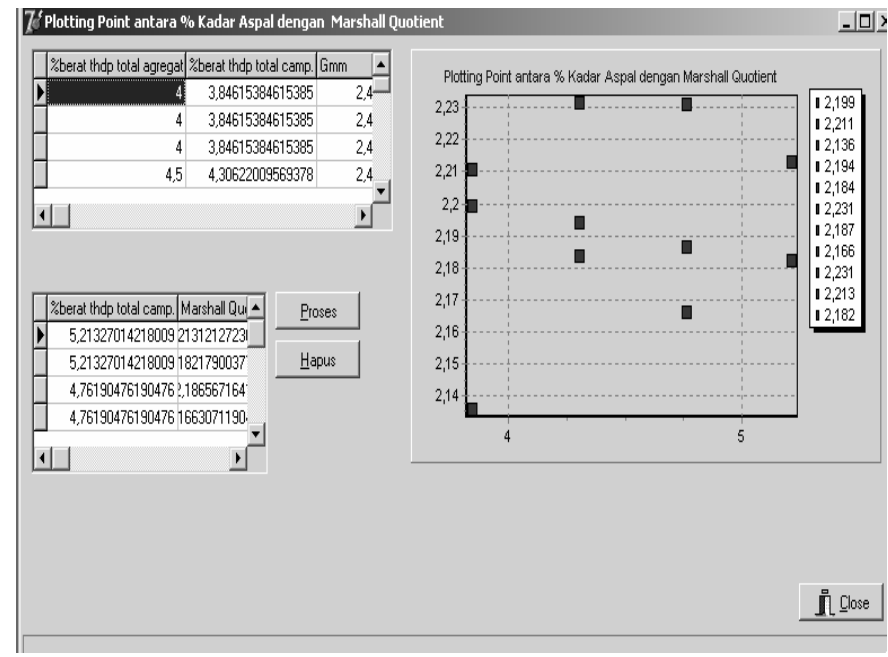

Gambar 3.7 Plotting point antara \% kadar aspal terhadap Marshall Quotient.

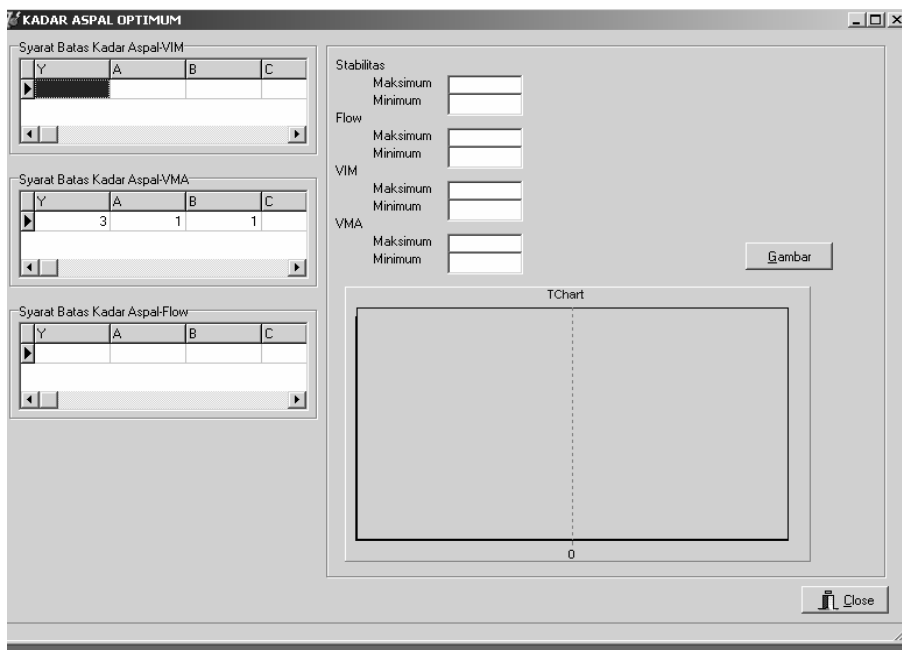

Gambar 3.8 Grafik kadar aspal optimum. 


\subsection{Algoritma Program}

Algoritma adalah urutan langkah-langkah logis penyelesaian masalah yang disusun secara sistematis.

1. Algoritma tabel perhitungan hasil pengujian Marshall.

a. Tentukan berat jenis apperent $\left(\mathrm{G}_{\mathrm{sa}}\right)$, berat jenis bulk $\left(\mathrm{G}_{\mathrm{sb}}\right)$, berat jenis aspal, $P_{s}$, kalibrasi proving ring, \% berat aspal terhadap agregat, $G_{m m}$, berat benda uji di udara, berat benda uji dalam air, berat benda uji kering permukaan, isi benda uji, bacaan dial, dan flow (kelelehan).

b. Lakukan proses penyimpanan dan pengolahan data dalam bentuk tabel database.

c. Akhiri program.

2. Algoritma perhitungan regresi polinomial.

a. Tentukan jumlah data $\mathrm{n}$, serta titik data $\mathrm{x}_{\mathrm{i}}$ dan $\mathrm{y}_{\mathrm{i}}$.

b. Lakukan inisialisasi koefisien persamaan simultan.

c. Selesaikan persamaan simultan dengan metode yang telah diberikan untuk mendapatkan harga koefisien persamaan.

d. Tulis hasil perhitungan.

e. Akhiri program.

3. Algoritma perhitungan plotting point antara $\%$ kadar aspal dengan $\%$ VIM.

a. Ambil data \% berat aspal terhadap total campuran dan \% VIM dari tabel perhitungan hasil perhitungan hasil pengujian Marshall.

b. Masukkan koefisien fungsi regresi dari hasil program.

c. Lakukan perhitungan dengan persamaan $y=a[0] x^{2}+a[1] x+a[2]$, dimana $\mathrm{a}[0], \mathrm{a}[1], \mathrm{a}[2]$ adalah koefisien fungsi regresi, $\mathrm{x}$ adalah data $\%$ berat aspal terhadap total campuran, dan y adalah \% VIM.

d. Plot titik x dan y.

e. Tentukan syarat batas.

f. Lakukan perhitungan dengan mempergunakan rumus abc untuk mendapatkan hasil $\mathrm{x}_{1}$ dan $\mathrm{x}_{2}$

g. Akhiri program.

4. Algoritma perhitungan plotting point antara $\%$ kadar aspal dengan \% VMA.

a. Ambil data \% berat aspal terhadap total campuran dan \% VMA dari tabel perhitungan hasil perhitungan hasil pengujian Marshall.

b. Masukkan koefisien fungsi regresi dari hasil program. 
c. Lakukan perhitungan dengan persamaan $y=a[0] x^{2}+a[1] x+a[2]$, dimana $\mathrm{a}[0], \mathrm{a}[1], \mathrm{a}[2]$ adalah koefisien fungsi regresi, $\mathrm{x}$ adalah data $\%$ berat aspal terhadap total campuran, dan y adalah \% VMA.

d. Plot titik $\mathrm{x}$ dan $\mathrm{y}$.

e. Tentukan syarat batas.

f. Lakukan perhitungan dengan mempergunakan rumus abc untuk mendapatkan hasil $\mathrm{x}_{1}$ dan $\mathrm{x}_{2}$.

g. Akhiri program.

5. Algoritma perhitungan plotting point antara $\%$ kadar aspal dengan stabilitas.

a. Ambil data $\%$ berat aspal terhadap total campuran dan stabilitas dari tabel perhitungan hasil perhitungan hasil pengujian Marshall.

b. Masukkan koefisien fungsi regresi dari hasil program.

c. Lakukan perhitungan dengan persamaan $\mathrm{y}=\mathrm{a}[0] \mathrm{x}^{2}+\mathrm{a}[1] \mathrm{x}+\mathrm{a}[2]$, dimana $\mathrm{a}[0], \mathrm{a}[1], \mathrm{a}[2]$ adalah koefisien fungsi regresi, $\mathrm{x}$ adalah data $\%$ berat aspal terhadap total campuran, dan y adalah berat volume.

d. Plot titik x dan y.

e. Akhiri program.

6. Algoritma perhitungan plotting point antara \% kadar aspal dengan flow (kelelehan).

a. Ambil data \% berat aspal terhadap total campuran dan flow dari tabel perhitungan hasil perhitungan hasil pengujian Marshall.

b. Masukkan koefisien fungsi regresi dari hasil program.

c. Lakukan perhitungan dengan persamaan $y=a[0] x^{2}+a[1] x+a[2]$, dimana $\mathrm{a}[0], \mathrm{a}[1], \mathrm{a}[2]$ adalah koefisien fungsi regresi, $\mathrm{x}$ adalah data $\%$ berat aspal terhadap total campuran, dan y adalah flow.

d. Plot titik x dan y.

e. Tentukan syarat batas.

f. Lakukan perhitungan dengan mempergunakan rumus abc untuk mendapatkan hasil $\mathrm{x}_{1}$ dan $\mathrm{x}_{2}$.

g. Akhiri program.

7. Algoritma perhitungan plotting point antara \% kadar aspal dengan Marshall Quotient.

a. Ambil data \% berat aspal terhadap total campuran dan Marshall Quotient dari tabel perhitungan hasil perhitungan hasil pengujian Marshall.

b. Masukkan koefisien fungsi regresi dari hasil program. 
c. Lakukan perhitungan dengan persamaan $y=a[0] x^{2}+a[1] x+a[2]$, dimana $\mathrm{a}[0], \mathrm{a}[1], \mathrm{a}[2]$ adalah koefisien fungsi regresi, $\mathrm{x}$ adalah data $\%$ berat aspal terhadap total campuran, dan y adalah berat volume.

d. Plot titik $\mathrm{x}$ dan $\mathrm{y}$.

e. Akhiri program.

8. Algoritma perhitunga grafik kadar aspal optimum.

a. Masukkan data nilai maksimum dan minimum dari data syarat batas.

b. Plot data pada gambar grafik.

c. Akhiri program.

\section{ANALISIS HASIL PROGRAM}

\subsection{Contoh Perhitungan}

1. Berat jenis bulk, $\mathrm{G}_{\mathrm{sb}}$ $=2,538$

2. Berat jenis aspal $=1,03$

3. $\mathrm{P}_{\mathrm{s}}$

$=96$

4. Berat jenis apparent, $\mathrm{G}_{\mathrm{sa}}$ $=2,644$

5. \% Berat aspal terhadap total agregat ( A ) $=4 \%$.

6. \% Berat aspal terhadap total campuran ( B

$$
\begin{aligned}
& =\frac{\mathrm{A}}{100+\mathrm{A}} \cdot 100 \\
& =3,846 \% .
\end{aligned}
$$

7. $\mathrm{G}_{\mathrm{mm}}(\mathrm{C})=2,443$.

8. $\mathrm{G}_{\mathrm{se}}(\mathrm{D})=\frac{\mathrm{G}_{\mathrm{sb}}+\mathrm{P}_{\mathrm{s}}}{2}$

$$
=2,591
$$

9. Berat benda uji di udara ( E ) = 1089,1 gram.

10. Berat benda uji dalam air $(\mathrm{F}) \quad=614$ gram .

11. Berat benda uji kering permukaan $(\mathrm{G})=1123,9$ gram.

12. Volume bulk ( H )

$=\mathrm{G}-\mathrm{F}$

$=1123,9-614$

$=509,9 \mathrm{~cm}^{3}$

13. Berat jenis bulk, $\mathrm{G}_{\mathrm{mb}}(\mathrm{I})$

$$
=\frac{\mathrm{E}}{\mathrm{H}}
$$

$$
=2,136 \mathrm{gr} / \mathrm{ml} \text {. }
$$

14. Kadar aspal yang terabsorbsi ke dalam pori agregat, $\mathrm{P}_{\mathrm{ab}}(\mathrm{J})$ 


$$
\begin{aligned}
& =100 \frac{\mathrm{D}-\mathrm{Gsb}}{\text { Gse } \mathrm{x} \mathrm{Gsb}} \times \text { berat jenis aspal } \\
& =0,83 \%
\end{aligned}
$$

15. Kadar aspal efektif yang menyelimuti butir-butir agregat, $\mathrm{P}_{\mathrm{ae}}(\mathrm{K})$

$$
\begin{aligned}
& =\mathrm{A}-\left(\frac{\mathrm{J}}{100}\right) \times \mathrm{Ps}_{\mathrm{s}} \\
& =3,20 \%
\end{aligned}
$$

16. VMA ( L ) $=100-\frac{\mathrm{IxP}}{\mathrm{G}_{\mathrm{sb}}}$

$$
=19,2 \%
$$

17. $\operatorname{VIM}(\mathrm{M})$

$$
=100 \times \frac{\mathrm{C}-\mathrm{I}}{\mathrm{C}}
$$$$
=12,6 \%
$$

18. $\operatorname{VFA}(\mathrm{N})$

$$
=\frac{100(\mathrm{~L}-\mathrm{M})}{\mathrm{L}}
$$$$
=34,6 \%
$$

19. Bacaan dial $(\mathrm{O})=61 \mathrm{div}$

20. Justifikasi $\mathrm{kg}(\mathrm{P}) \quad=\mathrm{Q} \times$ kalibrasi proving ring

$$
=716,010 \mathrm{~kg}
$$

21. Stabilitas Marshall ( Q ) $=\mathrm{R} \times$ faktor koreksi

22. Flow ( R )

$$
=687,4 \mathrm{~kg}
$$

23. Marshall Quotient ( S ) $=\frac{\mathrm{Q}}{\mathrm{R}}$

$$
=229,1 \mathrm{~kg} / \mathrm{mm}
$$

\subsection{Hasil Perhitungan dengan Program}

Hasil perhitungan dengan mempergunakan program ditampilkan dalam bentuk Tabel 4.1 
Tabel 4.1 Hasil Perhitungan Pengujian Marshall.

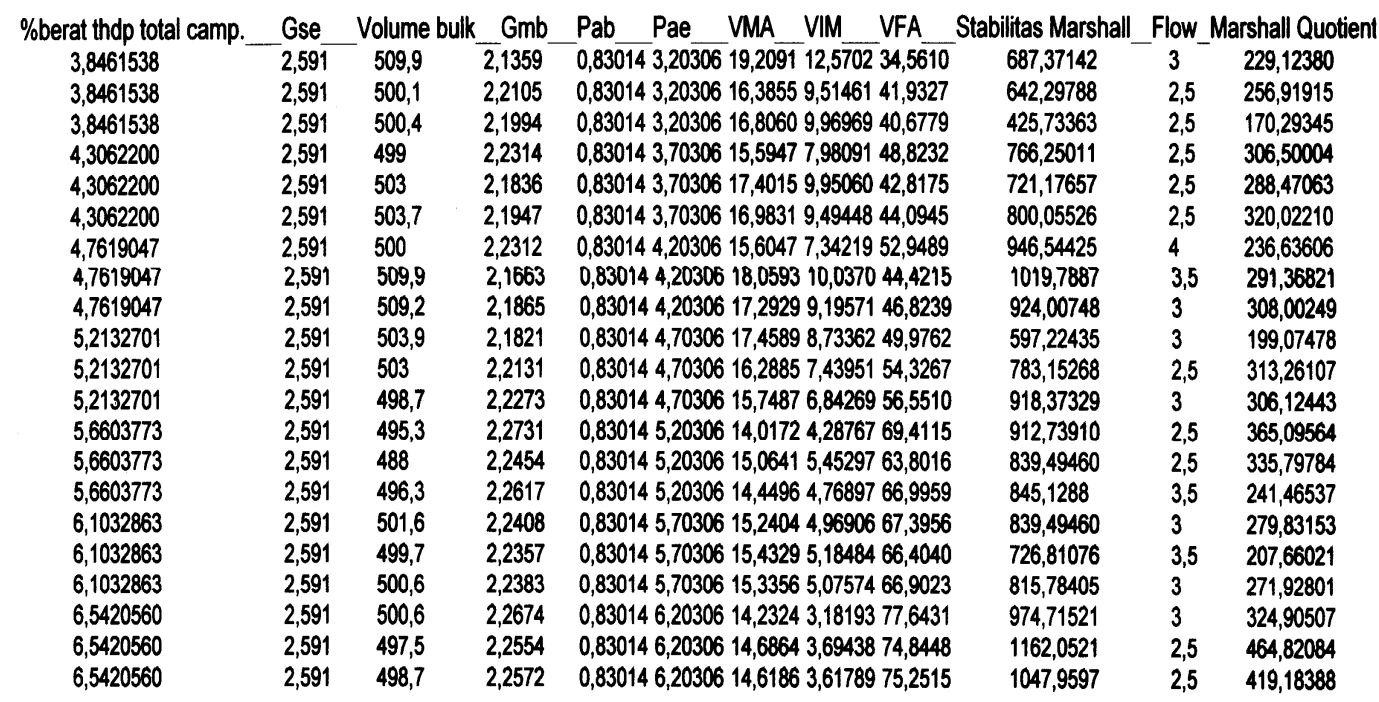

\subsection{Perbandingan Hasil Perhitungan Manual dan Perhitungan dengan Program}

\subsubsection{Perhitungan Uji t untuk VMA}

$$
\begin{aligned}
& H_{o}: \mu_{1}=\mu_{2} \\
& H_{a}: \mu_{1}>\mu_{2}
\end{aligned}
$$

Jumlah data $=21$

$$
\begin{aligned}
\overline{\mathrm{Y}}_{1} & =\frac{187,2000}{21}=8,910 \% \\
\overline{\mathrm{Y}}_{2} & =\frac{187,0842}{21}=8,909 \% \\
\mathrm{~S}_{1}{ }^{2} & =\frac{\mathrm{n} \times \sum \mathrm{Y}_{1}^{2}-\left(\sum \mathrm{Y}_{1}\right)^{2}}{\mathrm{n}_{1}\left(\mathrm{n}_{1}-1\right)} \\
& =76,598 \\
\mathrm{~S}_{2}{ }^{2} & =\frac{\mathrm{nx} \sum \mathrm{Y}_{2}^{2}-\left(\sum \mathrm{Y}_{2}\right)^{2}}{\mathrm{n}_{2}\left(\mathrm{n}_{2}-1\right)} \\
=76,324 & \mathrm{n}_{1}+\mathrm{n}_{2}-2 \\
\mathrm{~S}_{\mathrm{p}}{ }^{2} & =\frac{\left(\mathrm{n}_{1}-1\right) \times \mathrm{S}_{1}^{2}+\left(\mathrm{n}_{2}-1\right) \times \mathrm{S}_{2}^{2}}{\mathrm{~S}_{\mathrm{p}}}=8,744
\end{aligned}
$$




$$
\begin{aligned}
\mathrm{t} & =\frac{\overline{\mathrm{Y}}_{1}-\overline{\mathrm{Y}}_{2}}{\sqrt{\frac{\left(\mathrm{n}_{1}-1\right) \times \mathrm{S}_{1}^{2}+\left(\mathrm{n}_{2}-1\right) \times \mathrm{S}_{2}^{2}}{\mathrm{n}_{1}+\mathrm{n}_{2}-2}\left(\frac{1}{\mathrm{n}_{1}}+\frac{1}{\mathrm{n}_{2}}\right)}} \\
& =0,0004 \\
\alpha & =0,05 \\
v \quad & \mathrm{n}_{1}+\mathrm{n}_{2}-2 \\
& =40 \\
\mathrm{t}_{\alpha} & =1,684 \\
\mathrm{t} & =0,0004
\end{aligned}
$$

Karena $\mathrm{t}<\mathrm{t}_{\alpha}$, maka $\mathrm{H}_{\mathrm{o}}$ diterima, sehingga disimpulkan bahwa hasil perhitungan secara program dapat diterima.

Tabel 4.2 Perbandingan hasil perhitungan manual dengan hasil perhitungan program.

\begin{tabular}{|c|c|c|c|}
\hline \multicolumn{4}{|c|}{ VMA } \\
\hline \multicolumn{2}{|c|}{ Manual } & \multicolumn{2}{c|}{ Program } \\
\hline $\mathrm{Y}_{1}$ & $\mathrm{Y}_{1}{ }^{2}$ & $\mathrm{Y}_{2}$ & $\mathrm{Y}_{2}{ }^{2}$ \\
\hline 19,2 & 368,64 & 19,2091 & 368,9895 \\
\hline 16,4 & 268,96 & 16,3855 & 268,4846 \\
\hline 16,8 & 282,24 & 16,8060 & 282,4416 \\
\hline 15,6 & 243,36 & 15,5947 & 243,1947 \\
\hline 17,4 & 302,76 & 17,4015 & 302,8122 \\
\hline 17,0 & 289,00 & 16,9831 & 288,4257 \\
\hline 15,6 & 243,36 & 15,6047 & 243,5067 \\
\hline 18,1 & 327,61 & 18,0593 & 326,1383 \\
\hline 17,3 & 299,29 & 17,2929 & 299,0444 \\
\hline 17,5 & 306,25 & 17,4589 & 304,8132 \\
\hline 16,3 & 265,69 & 16,2885 & 265,3152 \\
\hline 15,7 & 246,49 & 15,7487 & 248,0216 \\
\hline 14,0 & 196,00 & 14,0172 & 196,4819 \\
\hline 15,1 & 228,01 & 15,0641 & 226,9271 \\
\hline 14,4 & 207,36 & 14,4496 & 208,7909 \\
\hline 15,2 & 231,04 & 15,2404 & 232,2698 \\
\hline 15,4 & 237,16 & 15,4329 & 238,1744 \\
\hline 15,3 & 234,09 & 15,3356 & 235,1806 \\
\hline 14,2 & 201,64 & 14,2324 & 202,5603 \\
\hline 14,7 & 216,09 & 14,6864 & 215,6903 \\
\hline 14,6 & 213,16 & 14,6186 & 213,7035 \\
\hline$\Sigma=187,2$ & $\Sigma=3197,16$ & $\Sigma=187,0842$ & $\Sigma=3193,1661$ \\
\hline & & & \\
\hline
\end{tabular}




\subsubsection{Perhitungan Uji t untuk VIM}

$$
\begin{aligned}
& \mathrm{H}_{\mathrm{o}}: \mu_{1}=\mu_{2} \\
& \mathrm{H}_{\mathrm{a}}: \mu_{1}>\mu_{2}
\end{aligned}
$$

Jumlah data $=21$

$$
\begin{aligned}
\overline{\mathrm{Y}}_{1} & =\frac{102,2}{21}=4,867 \% \\
\overline{\mathrm{Y}}_{2} & =\frac{102,22852}{21}=4,868 \% \\
\mathrm{~S}_{1}{ }^{2} & =\frac{\mathrm{n} \mathrm{x} \mathrm{Y}_{1}^{2}-\left(\sum \mathrm{Y}_{1}\right)^{2}}{\mathrm{n}_{1}\left(\mathrm{n}_{1}-1\right)} \\
& =23,715 \\
\mathrm{~S}_{2}{ }^{2} & =\frac{\mathrm{n} \mathrm{x} \sum \mathrm{Y}_{2}^{2}-\left(\sum \mathrm{Y}_{2}\right)^{2}}{\mathrm{n}_{2}\left(\mathrm{n}_{2}-1\right)} \\
\mathrm{S}_{\mathrm{p}}{ }^{2} & =\frac{\left(\mathrm{n}_{1}-1\right) \times \mathrm{S}_{1}^{2}+\left(\mathrm{n}_{2}-1\right) \times \mathrm{S}_{2}^{2}}{\mathrm{n}_{1}+\mathrm{n}_{2}-2} \\
& =23,707 \\
\mathrm{~S}_{\mathrm{p}} & =4,869 \\
\mathrm{t} & =\frac{\overline{\mathrm{Y}}_{1}-\overline{\mathrm{Y}}_{2}}{\mathrm{t}_{\alpha}}=1,684 \\
& =-0,0007 \\
\alpha & =0,05 \\
v & \mathrm{n}_{1}+\mathrm{n}_{2}-2 \\
& =40 \\
\mathrm{n}_{1}+\mathrm{n}_{2}-2 & -0,0007 \\
\mathrm{n}_{1} & \left.\frac{1}{\mathrm{n}_{2}}\right)
\end{aligned}
$$

Karena $\mathrm{t}<\mathrm{t}_{\alpha}$, maka $\mathrm{H}_{\mathrm{o}}$ diterima, sehingga disimpulkan bahwa hasil perhitungan secara program dapat diterima. 
Tabel 4.2 Perbandingan hasil perhitungan manual dengan hasil perhitungan program.

\begin{tabular}{|c|c|c|c|}
\hline \multicolumn{4}{|c|}{ VIM } \\
\hline \multicolumn{2}{|c|}{ Manual } & \multicolumn{2}{c|}{ Program } \\
\hline $\mathrm{Y}_{1}$ & $\mathrm{Y}_{1}{ }^{2}$ & $\mathrm{Y}_{2}$ & $\mathrm{Y}_{2}{ }^{2}$ \\
\hline 12,6 & 158,80 & 12,57020 & 158,0099 \\
\hline 9,5 & 90,25 & 9,51461 & 90,5278 \\
\hline 10,0 & 100,00 & 9,96969 & 99,39472 \\
\hline 8,0 & 64,00 & 7,98091 & 63,69492 \\
\hline 10,0 & 100,00 & 9,95060 & 99,01444 \\
\hline 9,5 & 90,25 & 9,49448 & 90,14515 \\
\hline 7,3 & 53,29 & 7,34219 & 53,90775 \\
\hline 10,0 & 100,00 & 10,03700 & 100,7414 \\
\hline 9,2 & 84,64 & 9,19571 & 84,56108 \\
\hline 8,7 & 75,69 & 8,73362 & 76,27612 \\
\hline 7,4 & 54,76 & 7,43951 & 55,34631 \\
\hline 6,8 & 46,24 & 6,84269 & 46,82241 \\
\hline 4,3 & 18,49 & 4,28767 & 18,38411 \\
\hline 5,5 & 30,25 & 5,45297 & 29,73488 \\
\hline 4,8 & 23,04 & 4,76897 & 22,74307 \\
\hline 5,0 & 25,00 & 4,96906 & 24,69156 \\
\hline 5,2 & 27,04 & 5,18484 & 26,88257 \\
\hline 5,1 & 26,01 & 5,07574 & 25,76314 \\
\hline 3,2 & 10,24 & 3,18193 & 10,12468 \\
\hline 3,7 & 13,69 & 3,69438 & 13,64844 \\
\hline 3,6 & 12,96 & 3,61789 & 13,08913 \\
\hline$\Sigma=102,2$ & $\Sigma=971,68$ & $\Sigma=102,22852$ & $\Sigma=971,61959$ \\
\hline & & & \\
\hline
\end{tabular}

\subsubsection{Perhitungan Uji t untuk VFA}

$$
\begin{aligned}
& H_{o}: \mu_{1}=\mu_{2} \\
& H_{a}: \mu_{1}>\mu_{2}
\end{aligned}
$$

Jumlah data $=21$

$$
\begin{aligned}
\overline{\mathrm{Y}}_{1} & =\frac{501,2}{21}=23,867 \% \\
\overline{\mathrm{Y}}_{2} & =\frac{501,404}{21}=23,876 \% \\
\mathrm{~S}_{1}{ }^{2} & =\frac{\mathrm{nx} \sum \mathrm{Y}_{1}^{2}-\left(\sum \mathrm{Y}_{1}\right)^{2}}{\mathrm{n}_{1}\left(\mathrm{n}_{1}-1\right)} \\
& =560,251
\end{aligned}
$$




$$
\begin{aligned}
\mathrm{S}_{2}{ }^{2} & =\frac{\mathrm{nx} \sum \mathrm{Y}_{2}^{2}-\left(\sum \mathrm{Y}_{2}\right)^{2}}{\mathrm{n}_{2}\left(\mathrm{n}_{2}-1\right)} \\
& =553,590 \\
\mathrm{~S}_{\mathrm{p}}{ }^{2} & =\frac{\left(\mathrm{n}_{1}-1\right) \times \mathrm{S}_{1}^{2}+\left(\mathrm{n}_{2}-1\right) \times \mathrm{S}_{2}^{2}}{\mathrm{n}_{1}+\mathrm{n}_{2}-2} \\
& =556,921 \\
\mathrm{~S}_{\mathrm{p}} & =23,599
\end{aligned}
$$

Tabel 4.3 Perbandingan hasil perhitungan manual dengan hasil perhitungan program.

\begin{tabular}{|c|c|c|c|}
\hline \multicolumn{4}{|c|}{ VFA } \\
\hline \multicolumn{2}{|c|}{ Manual } & \multicolumn{2}{c|}{ Program } \\
\hline $\mathrm{Y}_{1}$ & $\mathrm{Y}_{1}{ }^{2}$ & $\mathrm{Y}_{2}$ & $\mathrm{Y}_{2}{ }^{2}$ \\
\hline 34,6 & 1197,2 & 34,5610 & 1194,46 \\
\hline 41,9 & 1755,6 & 41,9327 & 1758,35 \\
\hline 40,7 & 1656,5 & 40,6779 & 1654,69 \\
\hline 48,8 & 2381,4 & 48,8232 & 2383,70 \\
\hline 42,8 & 1831,8 & 42,8175 & 1833,34 \\
\hline 44,0 & 1936,0 & 44,0945 & 1944,32 \\
\hline 52,9 & 2798,4 & 52,9489 & 2803,59 \\
\hline 44,4 & 1971,4 & 44,4215 & 1973,27 \\
\hline 46,8 & 2190,2 & 46,8239 & 2192,48 \\
\hline 50,0 & 2500,0 & 49,9762 & 2497,62 \\
\hline 54,3 & 2948,5 & 54,3267 & 2951,39 \\
\hline 56,6 & 3203,6 & 56,5510 & 3198,02 \\
\hline 69,4 & 4816,4 & 69,4115 & 4817,96 \\
\hline 63,8 & 4070,4 & 63,8016 & 4070,64 \\
\hline 67,0 & 4489,0 & 66,9959 & 4488,45 \\
\hline 67,4 & 4542,8 & 67,3956 & 4542,17 \\
\hline 66,4 & 4409,0 & 66,4040 & 4409,49 \\
\hline 66,9 & 4475,6 & 66,9023 & 4475,92 \\
\hline 77,6 & 6021,8 & 77,6431 & 6028,45 \\
\hline 74,8 & 5595,0 & 74,8448 & 5601,74 \\
\hline 75,3 & 5670,1 & 75,2515 & 5662,79 \\
\hline$\Sigma=501,2$ & $\Sigma=23167$ & $\Sigma=501,404$ & $\Sigma=23187,21$ \\
\hline & & & \\
\hline
\end{tabular}

$$
\begin{aligned}
\mathrm{t} & =\frac{\overline{\mathrm{Y}}_{1}-\overline{\mathrm{Y}}_{2}}{\sqrt{\frac{\left(\mathrm{n}_{1}-1\right) \times \mathrm{S}_{1}^{2}+\left(\mathrm{n}_{2}-1\right) \times \mathrm{S}_{2}^{2}}{\mathrm{n}_{1}+\mathrm{n}_{2}-2}\left(\frac{1}{\mathrm{n}_{1}}+\frac{1}{\mathrm{n}_{2}}\right)}} \\
& =-0,0012 \\
\alpha & =0,05
\end{aligned}
$$




$$
\begin{aligned}
v & =\mathrm{n}_{1}+\mathrm{n}_{2}-2 \\
& =40 \\
\mathrm{t}_{\alpha} & =1,684 \\
\mathrm{t} & =-0,0012
\end{aligned}
$$

Karena $\mathrm{t}<\mathrm{t}_{\alpha}$, maka $\mathrm{H}_{\mathrm{o}}$ diterima, sehingga disimpulkan bahwa hasil perhitungan secara program dapat diterima.

\section{KESIMPULAN DAN SARAN}

\subsection{Kesimpulan}

Dari hasil pemrograman perhitungan hasil pengujian Marshall dengan mempergunakan program Delphi dapat disimpulkan sebagai berikut:

1. Dengan hasil uji statistik diperoleh bahwa $\mathrm{t}<\mathrm{t}_{\alpha}$, maka perbedaan perhitungan antara manual dan program tidak signifikan, sehingga program dapat dipergunakan.

2. Kesalahan perhitungan dengan mempergunakan manual dapat diminimalisasikan dengan mempergunakan program.

3. Waktu yang dibutuhkan untuk menghitung dapat diperkecil, sehingga waktu jadi efisien.

\subsection{Saran}

Dari hasil pemrograman perhitungan hasil pengujian Marshall dengan mempergunakan program Delphi dapat disampaikan saran sebagai berikut:

1. Berdasarkan hasil pemrograman, dapat diberikan saran bahwa program ini diperlukan beberapa penyempurnaan yaitu kemampuan untuk menggambar grafik dan kemampuan untuk mencetak grafik.

2. Perlu pengembangan untuk modifikasi program untuk beton aspal tidak masif.

\section{DAFTAR PUSTAKA}

1. AASHTO (1990), Standard Specifications For Transportation Material And Methods of Sampling and Testing, Part II, "Test”, Fifteenth Edition, Washington,D.C.

2. Alam, M. Agus J., Mengolah Database dengan Borland Delphi 7, Elex Media Komputindo. 
3. Ardiansyah, Membangun Sistem Komputerisasi Laboratorium, Elex Media Komputindo.

4. Departemen Pekerjaan Umum, Badan Penelitian Dan Pengembangan PU, Standar Nasional Indonesia, Metode Campuran Aspal Dengan Alat Marshall, SNI 06-24891991; SK SNI M-578-1990-03.

5. Kadir, Abdul, Dasar Pemrograman Delphi 5.0, Penerbit ANDI, Yogyakarta.

6. MADCOMS., Pemrograman Borland Delphi 7(Jilid 1), Penerbit ANDI, Yogyakarta.

7. MADCOMS., Pemrograman Borland Delphi 7(Jilid 2),Penerbit ANDI, Yogyakarta.

8. Nasution, Amrinsyah \& Zakaria, Hasballah, Metode Numerik dalam Ilmu Rekayasa Sipil, Penerbit ITB Bandung

9. Sukirman, Silvia (2004), Beton Aspal Campuran Panas, Granit, Jakarta.

10. Sukirman,. Silvia (1997), Perkerasan Lentur Jalan Raya ., Penerbit NOVA.

11. Yuliquartiningsih, Deasy, Perbandingan Indeks Perendaman antara Campuran Beton Aspal Menggunakan Aspal Penetrasi 60 dan Aspal Penetrasi 80, Tugas Akhir, Universitas Kristen Maranatha, Bandung.

12. Zukhri, Zainudin, Dasar-dasar Pemrograman Visual dengan Delphi 6.0, Penerbit GRAHA ILMU. 